\title{
A Place of Pretense and Escapism: The Coffeehouse in Early 20th Century Budapest Jewish Literature
}

\author{
Mari Rethelyi \\ Department of Philosophy and Religious Studies, Louisiana State University, Baton Rouge, LA 70803, USA; \\ mrethelyi@lsu.edu
}

Received: 13 September 2018; Accepted: 16 October 2018; Published: 18 October 2018

\begin{abstract}
In Budapest, going to the coffeehouiennese Café and Fin-De-Siecle Cultuse was the quintessential urban habit. The coffeehouse, a Judaized urban space, although devoid of any religious overtones, was Jewish in that most of the owners and significant majority of the intellectual clientele were Jewish—secular and non-affiliated—but Jewish. The writers' Jewishness was not a confessed faith or identity, but a lens on the experience of life that stemmed from their origins, whether they were affiliated with a Jewish institution or not, and whether they identified as Jews or not. The coffeehouse enabled Jews to create and participate in the culture that replaced traditional ethnic and religious affiliations. The new secular urban Jew needed a place to express and practice this new identity, and going to the coffeehouse was an important part of that identity. Hungarian Jewish literature centered in Budapest contains a significant amount of material on the coffeehouse. Literature provided a non-constrained and unfiltered venue for the secular Jewish urban intellectuals to voice freely and directly their opinions on Jewish life at the time. In the article I examine what the Jewish writers of the early 20th century wrote about Budapest's coffeehouses and how their experience of them is connected to their being Jewish.
\end{abstract}

Keywords: Jewish Budapest; literature; coffeehouse; secular; rituals

\section{Budapest, the Urban, the Coffeehouse, and Jews Writing}

In turn-of-the-century Budapest, there was a special group of people visiting the coffeehouses. As in other European cities at the time, writers were among the coffeehouse's most fervent visitors. However, in Budapest, the intellectuals visiting the coffeehouses were in great numbers Jewish. This statistic could be attributed to the fact that journalism (journalism and literature were not separated, as most writers dabbled in both genres) was a career in which Jews and non-Jews were treated equally, with the same opportunities open to them. Journalism was one of the few careers that Jews could pursue, besides law and the rabbinate, that lifted them up into the middle class. Therefore, Jews flocked to journalism of all sorts (Kõbányai 2003, p. 6). Half of the journalists in Budapest were Jewish (affiliated with Jewish religious institutions). In 1890 46\%, in 1900 49\%, of journalists were Jews. A satire by Ferenc Molnár, ${ }^{1}$ titled The Dilettantes (Dilletánsok) articulates the trend of Jews increasingly pursuing careers as writers, because a writer sits in the café all day long and thus was viewed as a writer and artist by default.

The coffeehouse enabled the Jews to participate in and create culture. As Gluck puts it, the culture in the city "provided large segments of the Jewish population with new social identities that replaced traditional ethnic and religious affiliations. As actors and spectators in the public spaces of the city,

$1 \quad 1878-1952$. 
Budapest Jews both identified with and came to be defined by the urban institutions they helped create. They celebrated the imposing boulevards, the teeming coffeehouses, the lively music halls and the witty cabarets of the city, in which the Jews were embodiments of their own, as well as the city's, modernity." (Gluck 2016, p. 13). The writers' Jewishness was not a confessed faith or identity, but a lens on the experience of life that stems from their origins, whether they are affiliated with a Jewish institution or not, and whether they identify as Jews or not.

The new secular urban Jew needed a place to express and practice his urbanness. As Gluck highlights "the challenge of defining how to live under modern culture was met not by religious reformers but by the producers of urban popular culture. It is ordinary journalists, hack novelists, and producers of informal urban texts who shaped people's experiences and expectations of the urban environment. They created the image of the modern city, showing its inhabitants what the urban space looked and felt like. How it should be negotiated and consumed, and how its dangers might be managed and guarded against." (Gluck 2016, p. 18). That is, the secular Jew of Budapest set the blueprint for urbanness and going to the coffeehouse was an important part of it. The way Jews experienced the urban lay in the phenomenon of going to the coffeehouse and thus their Jewishness was connected to the coffeehouse.

The coffeehouse was a middleclass establishment, while the salons were for the aristocracy. While the aristocracy was an exclusive group, the bourgeoisie was not. Moreover, the middle class was in need for markers separate from the habits of the aristocracy (Lackó 1995, p. 2). Endre Nagy's² novella, The Last Days of a Usurer (Az uzsorás végnapjai), presents us with the ideal of being middleclass, best manifested by frequenting the coffeehouses. However, why would the Jews want to be middleclass in Budapest? Adolf Ágai ${ }^{3}$ describes in his novella, Izidor Kardhányó (Kardhányó Izidor), that in order for Jews to become middle class, they had to become Hungarian and, in certain aspects, imitate the aristocracy while at the same time establishing clear differences. Thus, it was important to have an establishment to frequent, as the aristocracy did, but it had to be a different establishment. Writers, intellectuals, and artists in Budapest, therefore, gathered in coffeehouses where they could mingle freely, and tended to dislike the salons. ${ }^{4}$

The coffeehouse culture in Budapest represented the dialogic and dialectical nature of Jewish experience of Judaism, manifested by the need to create new space that lacks religious content. Religion, as Thomas Tweed suggests in his book Crossing and Dwelling, is fluid, dynamic, relational and locative with rituals that can help orient the community and offer geographic centers. The coffeehouse functions as a fluid quasi-religious space in the sense that it served as a relational and locative communal center, a place to seek answers for life questions, where culture becomes the currency of exchange instead of religious beliefs. Going to the coffeehouse was a ritual like cultural performance that developed to restore some harmony in worldview; provide emotional balance and community, as Geertz's view of ritual suggests. The cultural performance of rituals enabled the enacting of roles and identities that were acquired by the very performance of the ritual of going to the coffeehouse. The coffeehouse became a central locative and relational social space that was endowed with religious-like meaning in a sense that the clientele formed a community that was made up of strangers who were connected by: a, inhabiting a larger locale from where they could access the same institutionalized space; $b$, the institutionalized space that existed for them as a place where they searched for ideas and found some mental and emotional satisfaction; c, attributing to the place special meaning with regard to their identity; $d$, feeling the need to frequent the place regularly in order to perform their identity.

\section{7-1938.}

1836-1916.

The establishment of salons as literary and art centers, as in Western Europe, did not work out in Budapest. Though throughout the 18th century there were several attempts such as the first by Podmaniczky Anna Maria in 1790, and even the Jewish salons of the Wohl sisters. 
Additionally, the coffeehouse as a secular space created a complex web of relationship between Jews and their host-cultures that enabled new identities to be imagined and performed. The coffeehouse was a place of innovation and openness that Jews could join. In return it had a major impact on Jewish life, and provided a new place to partake in the wider culture of the surrounding society in a less explicitly religious, secular, form. (Secular in this context means not belonging to a Judaism as a form of institutionalized religion, and being free from religious authority with regard to what and how one makes choices in life matters.) The disintegration of religious practices enabled the assimilation of Jews via new practices and modes of behavior, such as going to the coffeehouse, into the surrounding society. As Liberles writes: "The growing popularity of the coffeehouse for Jews has been seen as an indication of assimilation ... a barometer of assimilation." (Liberles 2012, p. xv). The coffeehouse as a ritualized non-religious space was used to continue pre-existing communal identities in the post-religious-institutional secular Jewish culture albeit in a more open-ended fashion. As Liberles says: "Coffeehouses have come to symbolize openness to new ideas and experiences." (Liberles 2012, p. 115). The new secular space of coffeehouse allowed a freedom of self-definition, to perform the self and the practice of identity envisioned, providing it with the tangible proof of the physical parameters of a spacial institution. Thus, the coffeehouse had an identity making aspect that enabled the Jews to be secular and members of a community where they could perform Jewishness that was imagined to be middle class urban intellectual. The coffeehouse created a structure and narrative of nonreligious Jews belonging into a secular middle class, a new community. Thus, Jews in the absence of religious space and rituals, sought new space and rituals to replace the old. The coffeehouse became such a space and the rituals or ritual-like habits performed in relation to it become quasi religious, filling the void created by the absence of religion, providing a venue to perform a new identity that was urban and intellectual. In this regard the Jewish clientele of the coffeehouse was a collections of individuals adhering to particular identity (urban, middle class intellectual) not faith (of Judaism).

How did being an intellectual relate to secular Jewishness and the coffeehouse at the time? And what was the role of literature as an element of culture in this Jewish life? For German Jews, as Hess claims, "literature enabled Jews to balance the multiple identities they had to contend with in a world in which questions as to who they were, what they did for a living, what they read, or who they would marry were no longer determined by the institutions of traditional Jewish life in the same way they had been in previous generations." (Hess 2010, p. 10). Also, literature was "secular in form and increasingly took on the task to of reinventing Jewish tradition, of remaking the Judaism of the past to render it compatible with the norms of a rising bourgeoisie..." (Hess 2010, p. 21). Similarly for Budapest Jews Jewish literature in the coffeehouse about the coffeehouse enabled to explore the new identity of secular Jewishness. As Jews moved out of the somewhat insularity of traditional Jewish world, and adapted middle class ideals of living and culture, literature became mediating ground of the new identity in the making. Literature, both making and consumption of it, was the visible and accessible battleground of the new Jew: middle class urban non-religious intellectual. As Hess argues that "popular literature played a crucial role in balancing multiple identities for Jews; that it helped sustain a sense of successful integration into the German bourgeoisie; and that it helped create a world in which Jewish identity could become a function of reading secular literature ... it promoted a distinctly middle-class identity for Jews as Jews." (Hess 2010, p. 14). Although the Hungarian scene is different from the German one because in Hungary modern Hungarian urban literature was mainly developed by Jews, literature likewise helped imagine their new Jewish identities in new ways and enabled them to see themselves belonging to a new world of Hungarian culture. A sense of collective belonging was developed in void of religious communal belonging, a kind of imagined community, though more tangible than Benedict Anderson's imagined community, because it was situated within the parameters of a physical space of the coffeehouse. Nevertheless, the effects of belonging to this new secular space spread out through the literature that was created within this space about the very space of the coffeehouse. Thus, the coffeehouse and its literature enabled Jew to imagine and perform a new identity through the ties to the physical space of the coffeehouse that was documented in literature. 
In this article, I examine what the Jewish writers of the early 20th century wrote about Budapest's coffeehouses and how their experience of them is connected to their being Jewish. My questions are: What was the coffeehouse for the Jewish writers of early 20th century? What did it symbolize and mean for them? What were the markers, and the ritual-like habits associated with the new secular communal space of the coffeehouse? I argue that all in all the Jewish literary imagination at early 20th century assumed a significant meaning to the coffeehouses, as a part of meaning making of the new secular Jewish-but-not-Jewish, urban, literary life. The coffeehouse became a source of identity for them, a new point of identification of a new society (secular, middleclass, intellectual, urban). As Gluck argues in her book, Invisible Jewish Budapest, their collective imagination was preoccupied with the idea and meaning of the coffeehouse. Whether Budapest really did have a huge number of coffeehouses or not, and whether Jews were a majority of the clientele and owners of these coffeehouses, is not really the issue. What matters is that the coffeehouse was adopted by Jewish intellectuals as a new communal-cultural living space. It was symbolic of a new home and community.

In this article, I study the writings of Jenõ Heltai (born and died in Budapest 1871-1957) a cousin of Theodor Herzl, who wrote numerous articles and poems for all the major leftist literary newspapers at the time, served as a director of several different theaters in Budapest and wrote some very famous plays, such as The Mute Soldier (A néma levente), that were made into popular movies in the 1930 ies. He survived WWII and communist Hungary awarded him the Kossuth prize in 1957, the highest official acknowledgement for contributing to Hungarian culture. Milán Füst, (born and died in Budapest 1888-1967) worked as a high school teacher while publishing novellas, poems and articles in the important literary journals of the time, such as Nyugat. He was not interested in writing for theater, like Heltai. He survived WWII and was awarded the Kossuth prize. Additionally, the Hungarian state established a prize for literature named after him in 1975; Sándor Bródy, born in Eger in 1863 and died in Budapest in 1923. He never finished formal schooling and was a Hungarian monoglott (a rarity at the time) who tried to earn a living by writing novellas and articles for newspapers in different cities of Hungary, among them Budapest. He never got out of financial troubles; Ernõ Szép (1884-1953), was a poet from the countryside who as a young adult moved to Budapest and worked as an editor and writer for the Nyugat. He survived WWII though not without difficulties. Some of his plays became famous in theater and were made into movies in the 1930 ies, such as Wisteria (Lila Akác). He died sick, poor and forgotten in the public sphere; Frigyes Karinthy, was a Budapester, born in 1887, who died from sickness in the country town of Siófok in 1938. He worked as a writer publishing numerous very popular and famous novels up to this day; Tamás Kóbor, in Pozsony was born in 1867 and died in Budapest in 1942. He worked as a banker in Budapest while contributing to several newspapers and journals; Béla Zsolt (1895-1949), came from the countryside to Budapest and worked there as a writer and politician, survived the holocaust, and participated in Hungarian post-war leftist politics; Adolf Ágai (1836-1916) came from the countryside to Budapest as a young adult. He was an important contributor to several newspapers in Budapest first as a humorist then as a journalist. The influential Borszem Jankó, a Jewish humor magazine was his creation that he launched in 1868; Ödön Gerõ (1863-1939) came form the countryside to Budapest as a young adult as well. He was a major contributor to important newspapers, such as Pester Lloyd and Tolnai Lexicon and was an active participant of the Jewish literary and art club in Budapest. All the writers mentioned generally knew some German, could speak and possibly write, but choose to write in Hungarian and confessed to Hungarian being their mother tongue. 
The writings of these intellectuals were published in the different newspapers and literary journals of the time in Budapest, such as: A Hét, ${ }^{5}$ Pesti Napló, ${ }^{6}$ Az Est, ${ }^{7}$ Nyugat ${ }^{8}$ Pesti Hirlap ${ }^{9}$ and Borszem Jank $\hat{o}^{10}$ and provide a window into the Budapest coffeehouse phenomenon. In this article, I choose to study the writings on the coffeehouse of these Jewish writers because they lived and worked in Budapest roughly at the same time, were coming from similar Jewish backgrounds, all choose to write novellas, novels and poetry in Hungarian, led a very similar lifestyle, that included frequenting the coffeehouses, and had similar intellectual pursuits of building up urban Hungarian (Jewish) literature. I looked at their writings on the coffeehouse form the 1870ies, when the coffeehouse boom started in Budapest till WWI, when the political, economic and cultural situation changed significantly together with the rise of anti-Semitism affecting Jewish presence in the coffeehouses.

\section{The Pretense of Being Middle Class}

In all cities of the monarchy, coffeehouse culture developed and blossomed during the second part of the 19th century. However, Budapest was at the extreme end of this phenomenon. Steven Beller argues, in the case of Jews and Vienna, that the idea that the Viennese café was a Jewish place, and that Jews belonged to the coffeehouse, though partially true, is misplaced (Beller 2015, p. 51). Jews were in the coffeehouse and they were a foundational part of the coffeehouse phenomenon, but the Jewish presence in and significance to the coffeehouse lay in secular Jewishness. In Budapest, just as in Vienna, the literary function of the coffeehouse predated the Jewish presence. However, unlike in Vienna, where Jewish writers used the coffeehouse to try to break into preexisting Viennese literary circles, or circles that existed in parallel to them, in Budapest, secular Jewish writers created the literary circles and they welcomed Jews and non-Jews alike. Furthermore, in Budapest at the turn of the century, many of the proliferating coffeehouses were owned by Jews. Additionally, since modern Hungarian literature was in its nascent phase (with a high percentage of Jewish writers) as Budapest was emerging as a metropolis, Jews were acculturating and secularizing. While in Vienna the Jewish literary coffeehouse was not part of the mainstream, in Budapest it was. The quintessential urbanite in Budapest was the Jew, unlike in Vienna. Additionally, Beller argues that the Vienna café was attractive for the Jews because it served non-alcoholic drink and one could do business and trade there. It became a gathering spot in place of the synagogue, though it was not exclusive but open to all. The Jew could pay for the cheap coffee and become a part of this 'club' of the café. On top of that, the Viennese Jews ran to the coffeehouse to escape anti-Semitism and its social exclusions. However, the situation was different in Budapest. Jews did not run to the coffeehouse due to anti-Semitism since it was not as rampant in Budapest as in Vienna at the time. ${ }^{11}$ Secular Jewish writers in Budapest went there for escaping economic reality while creating a virtual reality. Their identity as writers existed precisely because they went to the coffeehouse, where they wrote about the coffeehouse and formed a presence in the crowd and as writers. The coffeehouses they visited and the language they choose to write on were Hungarian.

1890-1924. A Literary and cultural journal based in Budapest.

1850-1939. A daily newspaper, appeared in the mornings in Budapest.

1910-1939. The most popular daily newspaper, appeared at noon in Budapest.

1908-1941. Literary and cultural journal in Budapest.

1878-1944. A popular daily newspaper of the liberal classes, free from political affiliations in Budapest. By the WWI it start to become more conservative and nationalist. It was the second most popular daily newspaper after the Az Est. Its writers were famous of the time such as Kálmán Mikszáth, Ferenc Molnár, Ferenc Heltai, Ferenc Hercegh.

10 1868-1938. A satirical journal in Budapest.

11 The negative effects of the well known fact that lots of Jews frequented the coffeehouses was that once anti-Semitism started increasing, there was another obvious place to go and look for Jews as The Est informs. Now naturally, not all coffeehouses had lots of Jewish clientele, but there were coffeehouses that had them. That is to say, that there was a semi-segregation, or preference where Jews went and where non-Jews went. The different classes of people tended to go, though there was no exclusivity of frequenting coffeehouses. The different coffeehouses served different clientele not just with regard to religio-cultural background, ethnicity, class but also interest. (Correspondent of the Est 1919, p. 4) 
The millennium celebration of 1895 became the symbol of Budapest's emergence as a European metropolis. That landmark resulted in the building of the city on a mass scale and the resulting growth was partly responsible for the explosion of coffeehouses to which Jews felt a special connection. There are no statistics that would tell us what percentage of Jews engaged in the cultural life of Budapest, as café-goers, but they were in great numbers according to the reflections of all contemporary writers (Zeke 1995, p. 3). However, we certainly know the percentage of Jewish writers in Budapest at the time among the literati who concocted a special relationship to the coffeehouse in their writings. On top of that, there are statistics about the ownership of coffeehouses. ${ }^{12}$ From what we know, Jews owned and operated about half of the coffeehouses and restaurants in Budapest. They certainly owned the most influential literary coffeehouses, such as Abbázia, ${ }^{13}$ Kairó, ${ }^{14}$ and Japán, ${ }^{15}$ despite the fact that coffeehouse business was not easy. As the non-Jewish Ferenc Herceg ${ }^{16}$ wrote: "No one can understand how the coffeehouse owner can make a living, even the coffeehouse owners themselves, therefore the coffeehouses change owners rather frequently." (Herceg 1903, p. 21). Because it was difficult to make money, owning and running a coffeehouse was a risky business. Doing so carried more of a cultural prestige than an economic advantage. Nevertheless, it was the dream of many to own one: "[T]he new owner is usually some small business person, who is attracted to the flashy business. They save up a bit in some small business, and then become coffeehouse owners. Then when they are broke, they go back to some other small business again." (Herceg 1903, p. 21). Thus, the owners changed often.

Numbers aside, the coffeehouse was considered to be a significant marker of Budapest's character. One of the Jewish writers, Viharos (Ödön Gerõ), writes at the time: Budapest "was the city of the coffeehouse [. If] someone wants to paint Budapest as the city, one needs to paint the coffeehouse." (Gerõ 1891, p. 81). Budapest was called the city of coffeehouses and "coffeehouse" became a symbol, a metonymy, for urban modernity (Gluck 2013, p. 295) and of the ultimate urban experience of Budapest itself. This phenomenon manifested in the idea that the very special disposition of Budapest was embodied in the existence of the coffeehouse. The Est describes the special character as, "the specific Budapester lifestyle and habits dictate that one spends less or more time of the day in the coffeehouse. The specialty of Budapest is the coffeehouse and the coffeehouse life. One concludes from this that the best coffeehouses are in Budapest. Not the most beautiful but the most well-run." (S.F. 1916, p. 12). In another edition, The Est explains in greater detail that "in Budapest the coffeehouse is not a luxury place or a place to loiter, but a special place of the city that aligns with its Balkan, oriental life and that is an organic part of the city's economic, political and artistic life." (Correspondent of the Est 1916, p. 4). Ernõ Szép concurs with the uniqueness of the coffeehouse in Budapest, writing: "I was in the nicest theater of Budapest last night. It was not a theater, not a variete, not a cabaret, not a cinema ... But the Mandl coffeehouse in the Király street." (Szép 1998, p. 42). Viharos provides an explanation about the specialness of the coffeehouse in Budapest. In his essay about Adolf Ágai's book Travel from Pest to Budapest (Utazás Pestrõl Budapestre), he writes that "the coffeehouse was considered to be a very special socio-cultural (társadalmi) institution..." (Viharos 1908, p. 7) that differentiated the small town/countryside from the urban metropolitan (nagyváros) space. Ferenc Herceg put it even more explicitly: "The coffeehouse made the countryside' Hungarian folk into urban middle class," (Herczeg 1985, p. 234). Going to the coffeehouse became the very thing that differentiated one as a Budapester from a countrysider.

In Jewish reflections, the coffeehouse became the prime space to visit in Hungary's only metropolis. The main attraction of the coffeehouse was that it was the embodiment of urban bourgeois life.

\footnotetext{
(Editor 1996).

Operated between: 1888-1985. Address: Budapest, VI disctrict, Oktogon 4.

Operated between: 1900-1945. Address: Budapest, VI disctrict, Lövöldw tér 6.

Operated between: 1890-1950. Address: Budapest, VI disctrict, Andrassy út 45.

1863-1954.
} 
Frequenting the coffeehouse in Budapest was considered the urban middleclass thing to do and Jews were a major part of it. As Budapest grew, the middle class grew, and the culture of coffeehouses grew and became well-established. Since Jews had a significant role in the creation of middleclass culture (polgári kúltúra) in Budapest, they had an important role in the making of coffeehouses. For members of the middle class to become a visible presence in Budapest society, they spent time in coffeehouses. A symbiotic relationship resulted: the coffeehouse needed the middle class for its survival and the middle class needed the coffeehouse to play being middle class.

Middleclass ideals were manifested, for example, in the interiors of the coffeehouses. The coffeehouse derived a powerful allure from an over-the-top interior, some pompous, some exotic-themed, intended to provide an experience that was extravagant and out of the ordinary. There were the Japán, Kairó, and New York coffeehouses with exotic names and with exotic interiors, all meant to stand out from the others. The exotic interior created a unique atmosphere. Lajos Nagy ${ }^{17}$ describes the Japan coffeehouse: "Japanese style paintings hang on the walls of the Japan coffeehouse ..." (Nagy 1956, p. 233). All the coffeehouses were a part of an unannounced competition in interior design. Szép describes this phenomenon of covert competition in his short novel The New Coffeehouse (Az új kávéház). The owner of a coffeehouse invested a lot in the plush interior, ambitious to make his café special in order to attract clientele. To attract customers, owners even advertised themselves and their exotic vision for their coffeehouses in the important magazines of the time.

It was also appealing to the middle class to have a venue where they could imagine themselves with an aristocratic bearing, with no time or work pressure and in the habit of being served. Since the small middle class in Budapest was still in the making, the definition of what the middle class entailed was still open. So all those who imagined, or wanted to imagine, themselves as part of the middle class, did so by drawing up a more or less semi-aristocratic lifestyle at an affordable price. This 'middle class' defined middleclass existence not necessarily by income but by outside markers such as where they were seen, where they were served, and the clothing they wore. This idea is described by Szép in his novella, Maestro (Nagymester) (Szép 1914a, p. 4). The server at the coffeehouse held a special status, linked with his ability to carry several coffees on a tray in a crowded room while keeping an eye on everyone. His elegant clothing, manner of carrying himself, and style of speaking were all marks of the quintessential urbanite for new immigrants from the country, like Szép himself. Being served by such a person made one feel included in a higher class than the server was (who was working class). Thus, being served put one between the aristocracy and the working class, thus the 'middle' class.

Additionally, the music in the coffeehouse elevated customers. The coffeehouses featured gypsy violinists, each one better than the one before, and soloists, who added to the glitter of the coffeehouse while the new 'Hungarians' smoked and drank different kinds of coffees sitting at the tables in groups, just like the aristocracy. In the coffee house one was a lord, served and waited on, and entertained by gypsies. So even the poorest citizen who went in to get a cup of coffee felt elevated in status and, for a moment, had a lifestyle that did not correspond to the reality of their living conditions. Even if all they owned was the clothing they wore and the price of a cup of coffee, they were aristocrats (Úr) in the coffeehouse as Sándor Bródy described in the novel On Andrassy street (Az Andrássy úton).

In the coffeehouse, one forgot all one's troubles, had good company in a plush place, and intellectual or easy conversations. Milan Fust reiterates this issue in Memories about Nagy Lajos and his circle (Emlékezések Nagy Lajosról és körüle). Even drinking coffee was once something for the aristocracy, where coffee drinking was a cultural event and not done merely for its enjoyment. This idea was carried into the coffeehouse, where drinking coffee was not the point, but a façade, that was about the culture of the coffeehouse-what one did there, how one behaved, dressed, and whom one saw and was seen by.

17 1883-1954. 
The affordability of the coffeehouse made it an inclusive, 'democratic' place since 'anyone' could enter. Democratic in a sense that anyone who was dressed in a certain way (middleclass) and could pay for a cup of coffee was welcome. There was a principle of accessibility and inclusivity in the coffeehouse. In the coffeehouse people came from different classes of society since most who could afford the price of coffee, which was cheap but served by well-dressed waiters (maybe better than the clientele), could enter and feel like the aristocracy or the new middle class. The real aristocracy or middle class were imagined not to be interested in going to the coffeehouse because they had no need to do so, since they had their own entertainment, servants, good food, and a heated home. Füst makes this point in a novella, where he asks one of his writer friends why he goes to the coffeehouse when he can afford not to, since he lives in a decent house. The friend says "there is peace in the coffeehouse. I drink my café, smoke my cigar, and think." (Gundel and Judit 1979, p. 185). Thus, the perceived need to go to the coffeehouse was the lack of money to afford a better lifestyle and the need to feel good about one's financial situation.

Jenõ Heltai wrote several poems addressing the issue of poverty, depression, and melancholy that stems from lack of money as the motivating factor to go to the coffeehouse. For example, Morning in the coffeehouse (Reggel a Kávéházban), he writes "Some poetic souls we are, sitting in the coffeehouse, and the truth is, it is not a nice life, the one we are living like this as if dreaming ... our home is a round table where in the middle of it the tea is steaming ... and when we step out to the street when the dawn comes, we go to sleep without dreams, and then we start our dream life again in the coffeehouse ..." (Heltai 1911b, p. 72). Heltai elaborates how the writers in the coffeehouse need to dream up a better life, for theirs is melancholic and poor. However, in the coffeehouse, they have friends, light, heat, and food as well. Another poem by Heltai, The Coffeehouse Elegy (Kávéházi elégia), talks about how "I love the coffeehouse, where my soul mates' melancholy faces, sad card playing, and dispirited idlers are." (Heltai 1913, p. 152.). They eat some food on credit in the warm coffeehouse, among crowds filled with interesting people and happenings, where a diverse group of people sit, drink, and eat with different manners that indicate their different socio-economic and demographic make-up.

Ágai, in his book, Journey from Pest to Budapest, has a whole chapter on the coffeehouses, where in a satirical fashion he goes though the different classes of people with dubious financial backgrounds who frequent the coffeehouse acting like the middle class. Among them are the writers: "What a waste of time, what people do in the coffeehouse. One cannot even fathom what the job of the clientele is," (Ágai 2017, p. 228) since they sit in the coffeehouse all day long. How do they earn money? They are not born rich like aristocrats and the middle class needs jobs to earn money. He claims that the ultimate magic of the coffeehouse is that "we never feel better anywhere else, as we run from the regulations and expectations of all forms of clubs, and we run here (to the coffeehouse) where freedom is absolute." (Ágai 2017, p. 244). That is, in both cases poverty and depression or melancholy stemming from one's difficult life and financial situation are a motivating factor to go to the coffeehouse where one seems to be able to escape one's reality and feel that he has a better life. Due to this function of the coffeehouse as a place of escapism, dreams, and illusions, it was very important that the coffeehouse was affordable for everyone.

The feeling of loneliness bordering on boredom, due to the lack of funds to do anything else in life, was another motivation to go to the coffeehouse. It was a place to find company, as is described in Szép's poem, The exhausting description of a lonely night wandering around (Egy magános éjszakai csavargás kimeritõ leirása). He writes "I am going to the coffeehouse, so that I can relax, I am ashamed of what I said, because I have no other social outlet, but to go to the coffeehouse and argue with the server." (Szép 1913). Szép continues, writing that as he "got out from the coffeehouse late at night" and went for an aimless walk in the city, because of the loneliness, melancholy, and lack of money, how at night the city is different. Because one is lonely and living in an under-heated and tiny home, and too poor to throw parties, travel, go to clubs, or even have a family, going to the coffeehouse meant feeling connected and being entertained. He further reflects on this lonely melancholy of the urban intellectual poor in another poem, Begging for snow (Könyörgés Hóért), lingering from one coffeehouse to another, 
stopping in the streets in the meanwhile, not knowing what to expect from life and unable to do much due to economic circumstances. Füst similarly describes the reason to sit in the coffeehouse: "It was light and warm in the coffeehouse, and if we stepped into it from the candlelight darkness of our circumstances, then we did not feel so much alone anymore. We had our friends and all our shelter there." (Gundel and Judit 1979, p. 185).

Another attractive element of the coffeehouses was the feeling of home. Since living conditions were bad for so many, and people did not even have a table to sit at let alone a warm room or light to read by, the coffeehouse became like home, as reflected in many Jewish writings. Ashby argues in her article that "one of the many things that the café offered writers and thinkers of all kinds was a place that was partially secluded, safe and home-like (private) as well as being integrated into the life of the city (public). The tensions among all these different aspects of the café played a major role in the vitality of the space." (Ashby 2015, p. 22). The coffeehouse could be visited any time of the day, unlike any other cultural institutions, such as theaters, cabarets, etc. It was open to anyone and was relatively affordable. In a novella by Szép, The Things in Life (Az Élet dolgai), the coffeehouse was described as a safe haven for all those who have lost their homes, and wanted to keep up the pretense of not being homeless, and in fact being middleclass. Even after the coffeehouses closed at 1 a.m., these people would behave as if they were open, by making use of the porches. Szép writes: "The coffeehouse is closed, but its porch is not closed and cannot even be closed, because it is outside on the sidewalk. People sit around in a good mood, chat, and breathe the air. The streetlights keep it bright for them. What do the guests of the coffeehouse drink after 1 a.m.? Fresh air, that is free ... They sit there for a long time stubbornly and do not mind the fresh air, the wind, the sky, because they are under the illusion that they are in the coffeehouse." (Szép 1916, p. 5). The coffeehouse had two parts, the inside of the building and the outside terrace that was cordoned off from the sidewalk. One of the two-inside or outside-was bound to be accessible twenty-four hours a day. As the story tells us, the inside had very generous opening hours, nevertheless it was closed late at night to early morning. The terrace was open all the time since it was a public space that belonged to the street. Being out on the street at night indicated one's financial difficulties, but sitting at the table of a closed coffeehouse was simply partaking of middleclass entertainment, albeit after hours.

The strong public sentiment about the affordable, i.e., democratic, image of the coffeehouse is evident in the growing importance of milkfroth during the war period. As the affordability of the coffeehouse eroded due to increasing economic hardship during wartime, milk, thus milk froth, became a sought after, hard to find, and expensive commodity according to a Jewish correspondent for The Est. (Fényes 1915, p. 2; Correspondent of the Est 1916, p. 4). As a result, coffeehouse owners raised the price of coffee, but met a vehement opposition from the public who had grown to expect that sitting in the coffeehouse and buying coffee would continue to be a very affordable activity. The outraged public claimed that the coffeehouse owners had no right to raise prices. They considered the affordability of coffee to be almost a basic human right. The public also claimed that it was the duty of the coffeehouse owners to figure out a way to run their businesses without raising prices, and thus making sure that everyone, even with little money, could afford to frequent them. After all how can the coffeehouse serve everyone-be inclusive-if it is not affordable for everyone (which was the assumed goal of the coffeehouse)? The coffeehouse, after all, existed for the people. If the public was unable to frequent it due to high prices, the coffeehouse would cease to live up to its raison d'être.

The 'democratic' character-meaning the affordability—of the coffeehouse, carried with it some negative effects as well. As a correspondent for The Est claimed: "In Budapest almost everyone is so irritated that even the cannibals do not think of eating each other so vehemently as we do here, where the air of the coffeehouse has corrupted the behavior of all of us." (Fényes 1914, p. 7). Not only the literati, i.e., the upwardly mobile or aspiring upwardly mobile demographic frequented the coffeehouse, but also criminals and members of organized crime groups, among them Jewish ones, as we can find in numerous accounts in The Est (Correspondent of the Est 1918, p. 2). For example The Est (Correspondent of the Est 1917, p. 8) features an account of Jewish swindlers who performed 
their business transactions in coffeehouses. Additionally, petty crime increased at the start of World War I, the effects of which were immediately felt in the coffeehouse.

The Est (Szép 1917, p. 7) reported a specific problem in the seamless functioning of the coffeehouse: the theft of matches. Due to the dire economic conditions of the war, even matches were an expensive, rare commodity. In addition, since one of the fundamental activities in the coffeehouse was smoking, matches were a vital resource. As coffeehouse culture evolved, matches were freely provided to the clientele, who supplied their own tobacco. The clients would light their tobacco and leave the box of matches on the table. However, during the war, people started to pocket the matchboxes and sell them. This practice disturbed not only the seamless functioning of the coffeehouse, but also created quite a financial problem as well and a cultural dilemma: should they uphold the previous cultural trend and provide matches for free in the coffeehouse or should they sell them? If the latter, would that affect the clientele-the "wannabe" middle class—and would they stop coming?

To recap thus far, the coffeehouse was a place of pretense and escapism for middleclass hopefuls, with its interior design and affordability that served such needs as food, entertainment, company, light, and warmth. It was a home for the semi-homeless, and made them feel like contributing and respected members of society. The coffeehouse was a marker of status and enabled people to escape from poor living conditions, and all the ailments that came with it: loneliness, boredom, insecurity, lack of confidence and human contact. The attractive elements of the coffeehouse introduced above (and its socio-cultural functions as outlined in the next section of the article), served an obsessive need to maintain a public face of middleclass urban life. Fashion dictated that being middleclass meant going to the coffeehouse. Thus, if one wanted to provide the image and live under the pretext of being middleclass, one needed to go to the coffeehouse. These elements of the coffeehouse were the markers of the new space for the Budapest secular Jewish intellectuals. This new secular space met the needs that emerged due to the descrambling of congregational ties and Jewish estrangement from religious spaces. In this new space, Jewishness was defined not by religious or ethnic ties, but by such markers as urban, secular, and middleclass.

For the self-appointed middle class who could not afford to go anywhere else, the coffeehouse was a cultural center. Why did people go to the coffeehouse? How did they receive culture there? It was a place to watch people, avoid boredom, and fill the void in every way since they had no money for other kinds of entertainment. All the freebies available in the coffeehouse were a focal point: newspaper, heat, reading lamps, a table to sit at, water to drink, a toilet. The coffeehouses were also famous for their library-like character and served as unofficial reading rooms. The best of the coffeehouses had all the important lexicons and books of the time, as well as several hundred newspapers from all over Europe-all there to impress. The coffeehouse meant getting information, knowing all the news, and being updated without having to pay for it. Coffeehouse clientele were addicted to the "news".

The newspapers that the coffeehouses were equipped with provided a worldwide, international context for the readers. As the novel of Mikszáth describes in The Newspaper Consumer (Újságfaló), a client who comes everyday to read through the vast array of domestic and international papers of the day; or in his A Bad Prescriber (Egy rossz elõfizetõ) where the main protagonist sits in the coffeehouse because he cannot afford to prescribe the newspapers to his house, thus he comes to do coffeehouse to read them. Szép also describes how reading the newspapers was fundamentally connected to the coffeehouse in his short essay on the Newspaper Readers (Újságolvasók). The urbanites who read the newspapers in the coffeehouse could not afford to buy them for home. "I am going to the coffeehouse because of the newspapers ... The newspaper boy brings me all the newspapers where I sit in the corner of the coffeehouse, as if the coffeehouse would be the world that I do not want to mingle with, but only observe the lives of people from here (from the corner of the coffeehouse) from the end of the world."(Szép 1914b, p. 4). There are those, who took the whole day to read through all the papers, and kept a huge stack of them on their table. However, why? Szép's answer is "boredom, he has no friends, and the only way he can spend time is reading newspapers. I have seen plenty of these lonely newspaper-readers in the coffeehouses of Pest, who read like sportsmen, 
and are prisoners and monks of the world's news staggered on the shelves of the coffeehouse." (Szép 1914b, p. 4). In another short novel, The Billiard (A billiárd), Szép remembers his student years when he "followed the fashion of the time and naturally spent more time in the coffeehouse than at the university. [He] was always sitting in a beautiful inner city coffeehouse, because all the law students like [him] were registered (matriculated) there." (Szép 2003, p. 15). He claims he "learned a lot about society, people, and about the city while sitting in the coffeehouse, staring at everything and everyone around him, with Saturday being the day of celebration, as all the new magazines and newspapers arrived Saturday. It was my special celebratory hour when I collected all the beautiful papers and looked at them ..." (Szép 2003, p. 15). The coffeehouse, thus, was a place to see the world through the news, as well as be in a community and observe the surroundings.

Hungry for community, entertainment, and culture, writers chose the coffeehouse as their meeting place. The coffeehouse was an affordable space of culture, a destination that drew similar minds, and an institution where ideas old and new could be shared and tested. It was a place of observation, meditation, self-reflection, societal participation, a crucial social hub for similar people. It was a venue for the propagation and dissemination of new ideas, where one could enter and exit anytime one wished. As Szép describes: "In the hour of black (coffee) the best representatives of literature came to the coffeehouse, and the hour of black was determined by everyone on an individualistic basis. Thus, the coffeehouse was full of youngsters and old ones day and night who sat in the smoke and left usually without paying." (Heltai 1911a, p. 1). They wanted the companionship of likeminded people, the people they knew, and also the atmosphere: the window to the outside (society) and the inside (social dynamics). Sitting in the coffeehouse provided a lifeline to topics and inspirations for writing, as well as literary and social connections.

The coffeehouse also provided people with an audience. It was the stage where opinions were voiced while loneliness-whether intellectual or physical—was avoided. As Zsolt Béla put it: "The plants of Pest, like the people of Pest, get life from coffee" (Zsolt 2002, p. 277) since everyone was in the coffeehouse. Writers went there to write, to read, to talk, and to have friends: "Literature wanted to live its own life in the coffeehouse." (Fábri 1993, p. 161.). Writers' circles gathered at tables to hold journalist meetings (Borszem 2000, p. 2). The tables became "theirs" as they carved out a place out for themselves in the café. They created a space not only physically but also in the public mind, where they, as writers, existed in connection to the coffeehouse. Without the coffeehouse, a person was unknown and lost in the metropolis, but, within the coffeehouse setting, one could be known and one's presence was closely watched, for better or worse. Ágai in the satirical paper, Borszem Jankó, published several jokes about writers working in the coffeehouse, illustrating that the coffeehouse was a well-known trope. In one, two writers in a coffeehouse are discussing intellectual matters. One writer claims, "Together we are smarter than Brandeis [a well-known foreign intellectual]. The other quips, “Together? Bah! I alone am smarter than Brandeis!" (Borszem 1915, p. 9). Thus, the intellectual status of the Budapest coffeehouse literati is confirmed and even Americans do not measure up to them. Jokes could shape and quickly spread impressions and beliefs among the populace.

\section{Buying Culture for a Cup of Coffee}

In addition to its role as an affordable social hub, the coffeehouse was a fundamental factor in creating the urban identity of Jewish writers. From Jewish novels of the period, we can decipher the notion that, in order to maintain the specific Budapest (urban) identity, one needed to frequent and linger in the coffeehouse. Heltai addressed this topic in his novel, About the Death of a Coffeehouse (Egy Kávéház halálára), where he tells how people had a responsibility to frequent an establishment so that it would not go out of business. Since the coffeehouse was the lifeline of the city, and the focal point for the citizenry mingling and talking about ideas, everyone had to keep it alive. It mirrored and supported society.

Some people frequented several coffeehouses and never went back to the same, and they enjoyed the fact that the experience was always new. Others became regulars (törzsvendég), which carried 
prestige with it. In the café, they made themselves accessible and visible. Just as in the Viennese coffeehouse, the writers' circles with the Stammtische (törzsasztal) were similar in both capitals of the monarchy. As Ashby argues in her article, the Stammtische made the group visible and approachable. The groups were fluid and permeable. One had by the repetition and reputation 'assigned' table and drink, came at an assigned time every day, and sat with the same people. The recurring sameness was the desired aim and it gave the consumer the prestige of being known. In his novel, The Regular (Törzsvendég), Heltai talks about the meaning of being a constant permanent consumer in a coffeehouse and why it was good, saying that "a regular is the person who has a reserved table at the coffeehouse, who arrives exactly at the same time every day to the same place, who is very keen on being served by the same waiter every time, who wants the same newspaper to be put front of him on the table all the time, who hangs his coat and hat on the same hanger. It is a mystery that the person who looks upon entertainment and relaxation as work, and one office does not suffice for him, but voluntarily takes on other two-three, the coffeehouse, the pub, and frequents them with the same strict consciousness (lelkiismereteséggel)." (Hay 2002, p. 75).

It was important to linger long in the coffeehouse, to spend lots of time there. The pride of the coffeehouse was based on the number of regulars. As Bródy put it: "Besides good coffee while smoking, to watch people work, that is my daily entertainment, that never bores me, and when I think of death, it is specially inconvenient and bothersome to me, because I will not be able to frequent the coffeehouse anymore." (Hay 2002, p. 64). The main server (fõpincér) was typically a unique character and always well-known to the regulars. As Kóbor describes in his short essay, Guszti, the main server (Guszti, a fõpincer) (Kóbor 1999, p. 162) elaborates on the special relationship that existed between the regular and the main server. They valued each other. The server made the regular feel like aristocracy, and the regular empowered the server in his position by treating him specially. For the coffeehouse owners and main servers, it was a prestige that famous writers wrote in their coffeehouses. With less famous writers they just hoped that they would be famous one day, thus, banking on a future endorsement of their coffeehouse. Writers, who want to meet and make connections, and non-writers, who wanted to see the spectacle, met daily in the same space, assuming they could intellectually and culturally benefit from it (Gundel and Judit 1979, p. 229).

However, not all coffeehouses served the same purpose and thus differed in their role in identity making. Writers frequented several different coffeehouses for different purposes. Though there were some coffeehouses that became a central place for writers, such as the Fiume or the Abbázia (where Heltai liked to write, and where The Est's table was, for example), usually, different coffeehouses carried different literary-prestige and hosted different groups of writers. Up-and-coming and aspiring writers knew in which coffeehouse at what time the already established or known writers were to be found, and they could seek them out. Or, if they wanted to join a writer's group or a journal they knew in what coffeehouse 'the table' of that journal was and they could approach it. In this way the coffeehouse enabled the connections to form. How much the character of the coffeehouse depended on where it was situated, and, thus, what kind of writers it attracted, is apparent in Kóbor's words: "The street where it (Gutfreud coffeehouse) is located determines the coffeehouse's character." (Gundel and Judit 1979, p. 231).

Different writers preferred the different coffeehouses, generally speaking, and even more, different writers preferred to write different genres, or write about different topics in different coffeehouses. For example, as László Márai ${ }^{18}$ points out in his article, The writer and the City (Az író és a város) (Márai 1945, p. 125) on Karinthy that the city and the writer were organically interrelated and influenced by each other. Karinthy had three coffeehouse bases, Hadik, Central, and New York coffeehouses. When one reads Karinthy's writings, one can tell what was written in which of the three coffeehouses based on the topic. Hadik had small windows, and one could not escape observing

18 1900-1989. Writer and Journalist. 
the social dynamics among the clientele of the coffeehouse. Thus, topics for writing in the Hadik included: women, society, and family. It was there that Karinthy wrote Please teacher (Tanár Úr kérem). The Central coffeehouse was in the university district and its window overlooked the university library. Thus, Karinthy wrote about teaching and science such as Travel around my skull (Utazás koponyám körül). The New York coffeehouse overlooked the main thoroughfare of the boulevard (nagykörút), where he could see the life of the city. It was in that coffeehouse where he wrote about city life and politics in his novels: Memories of Budapest (budapesti emlék), This is how you write (Igy írtok ti).

The identity-making aspect of the different coffeehouses, for both the writer and his writing, is further expressed in a short story by Ferenc Székely ${ }^{19}$ titled, "The Kagal" (A kagál) (Székely 1918, p. 8), from the satirical paper, Borszem Jankó. The story tells how the Jewish writers who aspired to establish a journal and a writers' association went from coffeehouse to coffeehouse until they found their identity as a group of writers. The search for the 'right' coffeehouse was essential in this identity-journey. It provoked the writers to think of themselves as a group. Finding the coffeehouse that fit had a great deal to do with atmosphere, including the view, location, décor, and clientele. All these aspects were essential in deciding where the writers felt at home. Conversely, the coffeehouse where they felt they fit, in turn, influenced the topic and genre of their writings in fundamental ways.

The coffeehouse as an urban intellectual identity maker is featured in period novellas. A certain self-awareness is evident in the coffeehouse novellas where the coffeehouse is simultaneously the subject matter and the background of the stories. The writers, whether significant or less significant, wrote about what they observed in the coffeehouse. They wrote about this setting in two essential ways. One, they wrote about each other and what they observed the other doing in the coffeehouse. By doing so, they created the image of the café-based writer. One could know which writer sat at what time of the day in what café and what table, and could even observe the writer in his or her creative moments in each other's writing. In the novel by Karinthy A Theme that seeks a writer (Egy téma írót keres), "He found Ernõ Szép in the coffeehouse as Szép was contemplatively following with his eyes a rolling down water drop on the window." (Karinthy 1958, p. 383). Karinthy goes on elaborating how this image of Szép was like a painting, and then continues to ponder about Szép's character (Ayha 2011, p. 96) in this way mystifying each other sitting in the coffeehouse became an allure of the coffeehouse for everyone.

In the second way that writers, such as Szép and Kóbor, incorporated the coffeehouse was to use the background as an integral part of their novellas. Thus, while reading the novella, one could see what was happening there through the eyes of the writer, as if the reader was the writer and was witnessing what was going on in the coffeehouse. We can see how frequenting the coffeehouse was a maker of urbanness, for these stories simultaneously provided subject matter for writing as well as a basis for a writer's identity.

The coffeehouse served as more than a meeting place for intellectuals and writers to discuss ideas and write novels. It was also a public space for observing social dynamics. For example, it was a place to meet marriageable partners, and where romance and relationships played out in a public way. In Kóbor's The old dear (A régi kedves) (Kóbor 1902, p. 2), he describes how the coffeehouse was not only a place to find someone suitable for marriage, but was also a place where one could observe how those marriages evolved. Another example for integrating the coffeehouse as a social center and arena for social observation, is a story by Frigyes Karinthy, The blessed hand that hits (Az áldott kéz, mely üt). In this story, the coffeehouse is a spontaneous meeting place viewed through the writer's lens. The protagonist's actions and connection to people is on full display in the coffeehouse, and while he sits there, his life becomes an open book-one that the reader/writer can piece together by simply sitting and watching. Szép's short novella, What is the time? (Hány óra?), even makes fun of how people know everything by simply sitting in the coffeehouse observing the surroundings. The poor

19 1858-1934. Banker, journalist. 
protagonist of the story does not have a watch. He had to sell it due to lack of money. However, he does not need it, he only needs to sit in the coffeehouse all day and he can tell the time within five minutes based on what is happening in the coffeehouse and on the street. For example, when do the bakers bring the bread to the store, who goes to work or to school, when does the mailman pass by, when do the stores open and close, who comes in (from what social strata) to the coffeehouse etc.

In another novella, The Newspaper seller (Az Újságos), Szép tells us about the tragedy of the newspaper seller who sells the newspapers in the coffeehouses, but then loses his job. He is in some ways a complete stranger (as the only interaction through the years was between buyer and seller), but in other ways is an old acquaintance of the writer (since they have interacted with each other for years). The regulars in the coffeehouse collect a charity for him so that he and his family can survive while he is looking for a job. The story highlights how the coffeehouse is not only a place of social mingling where the different social strata meet and witness each other's lives and problems, but where society actually forms. The familiarity that the coffeehouse breeds breaks down class, religious, and ethnic barriers, and forms one cohesive group of people who give charity to each other when life demands.

The city-society—is visible from the coffeehouse and one becomes a part of society only by being in the coffeehouse. Szép has numerous other short novellas whose stories are tightly linked to the coffeehouse culture, such as Kati come out (Kati gyerek ki) (Szép 1945, p. 119). Jenõ Heltai's The Last Bohem (Az Utolsó Bohém) (Heltai 1911a, p. 1) is a novella that elaborates on a habit that is centered in the coffeehouse. He became an expert in betting on the horse races simply by sitting in the coffeehouse, listening to the information on horse racing that was accessible to him there, and observing the social dynamics of betting.

When a writer sets stories in the coffeehouse and allows the reader to experience the setting and people through his or her eyes, the coffeehouse is both demystified and set apart as a special place. It is a place where the individual mingled with society and had the opportunity to meet cultural celebrities such as writers and artists. The meeting of people and their ideas was perceived and interpreted as a cultural exchange. A coffeehouse was a place to make a mark and for ordinary people to become famous by becoming part of the cultural narrative. The coffeehouse was therefore a social and intellectual hub that enabled, created, and maintained culture celebrated in the Jewish writings. In this way the coffeehouse revered itself, celebrated itself through its image in the literature. The culture it presented was fluid, permeable, and inclusive since it was a free place to enter and exit. In a time of bleak poverty, people needed more than physical necessities. Receiving and creating culture elevated coffeehouse clientele and allowed them to be part of an overarching cultural exchange.

\section{Conclusions}

What did the coffeehouse mean for the Jewish writers in Budapest? Going to the coffeehouse was the quintessential urban habit. In Budapest, it was also a quintessentially Jewish habit. Though not an overtly Jewish place, the coffeehouse was a kind of replacement for religious communities from which many Jews were estranged. The coffeehouse was Jewish; however, only to the extent that the urban middle class in Budapest was very Jewish at the time, as was the aspiring middle class. Thus, a Judaized urban space, void of any Judaism in religious terms, was Jewish in that most of the owners and a significant majority of the intellectual clientele were Jewish—secular and non-affiliated, but Jewish.

Budapest's rise as a metropolis went hand in hand with the birth of its middle class and the emancipation of Jews, where Jews modeled the middle class. As a middle class they had the means and the need to pursue intellectual activities, which replaced the religious-Jewish ideal of studying Torah. Thus, in Budapest, the coffeehouse was Jewish at the turn of the 20th century, and the intangible secular urban Jewish experience of the city, as a city en large, was the coffeehouse experience. Nothing was particularly Jewish about it, though Jews owned a lot of coffeehouses and frequented them. The middle class was mainly comprised of Jews. Assimilated and non-religious Jews became a majority among 
the Jews of Budapest. They had no gathering place anymore, no synagogues. However, they needed a place to go, to belong, to gather, to feel that they had a respectable assigned place in society. There were not many choices for the new middle class of assimilated Jews. This need was fulfilled in the existence of the coffeehouse as the new synagogue, as a gathering place, not a place of worship. Since drinking coffee, previously an aristocratic habit, was adapted by the middle class, the coffeehouse became a natural place for socializing, a new temple of non-religious Jewish writers.

In Budapest, Jews became the showpiece of urbanness. Their visibility in the coffeehouse enabled one to tell the urbanite (pesti) apart from the people from the countryside (vidéki) (i.e., people not form Budapest). Recent immigrants to the city from the countryside were afraid of embarrassment by being so unaware of proper behaviors. As Sándor Bródy wrote: "I was afraid, that now immediately, I will be outed, that I do not know Hungarian orthography, and the whole world will know it." (Lackó 1995, p. 112). There are several stories about the behavior of the Galician Jews (galiciaiak), who stood out in the coffeehouse because of their country mannerisms. For example, in a novella, Faragó (1915, p. 14) described the different guests of the coffeehouse, and how apparent their backgrounds were based on how they were grouped at various tables and in what activities they were engaged. He goes on to describe how the Galician tried to learn urban coffeehouse behavior by observing the Pesters (pestiek), apparently the epitome of proper coffeehouse etiquette. The Galicians were modest, shy, and did not know how to behave in the coffeehouse, while the Pesters, middle-class Jews and coffeehouse regulars, displayed confidence in what they were doing and how they were doing it. Furthermore, the coffeehouse was the place where one could meet fellow Galicians, and through them one could get oriented in the city and break through the isolation new immigrants inevitably experienced, being alien to the urban environment. (Correspondent of the Est 1915, p. 2). For the secularized, aspiring, urban, penniless Jewish writers, the Galicians, the coffeehouse created a possibility of meeting and forming a new or becoming part of an established society that was urban, up-and-coming, and upwardly mobile. The coffeehouse enabled citizens to see Budapest and imitate the people of Budapest, and through imitation become Budapesters. How? By dressing up and sitting in the coffeehouse as the quintessential urbanites-the Jews—did it. Imitating them meant becoming an urbanite. Coffeehouse culture was the expression of urbanness and the maker of urbanness at the same time.

We see that the coffeehouse was considered to be the quintessential urban space where existing rules of society did not apply, and habits could be bent. It was a space in the city where boundaries could be temporarily transgressed, a new home where one could feel elevated into the middle class. The coffeehouse taught one to behave like an urbanite. As Heltai put it: "The coffeehouse teaches its clientele better behavior, politeness, ethics. It gives newspapers into their hands, and acculturates, educates and enlightens." (Gundel and Judit 1979, p. 185). Due to the collective homelike view of the coffeehouse it was a place to avoid loneliness, from where one could watch the urban crowd stroll down the street and observe life happening.

It was also a place of identification for the writers where the Jews and the non-Jews sat together, in the words of Kosztolányi, "above coffee in the smoke of cigarettes, they talk about politics, arts, women: they wrote articles, poems, and novellas. The writers may even get coffee on credit. What happens in this country, happens here." (Zeke 1995, p. 3). The Jewish writers "Bródy Sándor, Molnár Ferenc, Heltai Jenõ saw first and clearest from here what is special in the life of this capital city ... They wrote, and they listed everything that was interesting and special in Budapest," (Csáth 1987, p. 3) while sitting in the coffeehouse. They wrote about the coffeehouse as a part of urban Budapest experience. In addition, the urban intellectuals created a cultural home out of the coffeehouse. Thus, the Jewish experience of the urban lies in experiencing the coffeehouse, which gave a new point of identification for secular Hungarian-Jewish writers. The culture received and produced there was a replacement for religious contents. The Jewishness of Budapest that we read about can be found in this place- the coffeehouse, the ultimate urban phenomenon of late 19th century Budapest, where Hungarian Jews found their dreamed-of home, at least for a time. 
Funding: This research received no external funding.

Conflicts of Interest: The authors declare no conflicts of interest.

\section{References}

Ágai, Adolf. 2017. Utazás Pestrõl Budapestre. Budapest: Fekete és Sas Kiadó.

Ashby, Charlotte. 2015. The cafés of Vienna. In The Viennese Café and Fin-De-Siecle Culture. Austrian and Habsburg Studies. Edited by Charlotte Ashby, Tag Gronber and Simon Shaw-Miller. New York: Berghahn Books, vol. 16.

Ayha, Gökhan. 2011. Szép Ernõ a kávéházban. Budapest: Látó Szépirodalmi Folyóirat.

Beller, Steven. 2015. 'The Jew belongs in the Coffeehouse': Jews, Central Europe and Modernity. In The Viennese Café and Fin-De-Siecle Culture. Austrian and Habsburg Studies. Edited by Charlotte Ashby, Tag Gronber and Simon Shaw-Miller. New York: Berghahn Books, vol. 16.

Borszem, Jankó. 1915. A telefonisták. Borszem Jankó, August 22, 9.

Borszem, Jankó. 2000. One. Borszem Jankó, April 8, 2.

Correspondent of the Est. 1915. Razzia a Royal-börzén. Az Est, October 16, 9p.

Correspondent of the Est. 1916. A kávésok ismét emelik az árakat. Az Est, February 29, 4p.

Correspondent of the Est. 1917. Kohn Lajost az ügyézséghez viszik. Az Est, August 19, 8p.

Correspondent of the Est. 1918. Nagy Razzia a kávéházban. Az Est, November 24.

Correspondent of the Est. 1919. Az 'ébredõ Magyarok' gyūlése a Gólyavárban. Az Est, January 21.

Csáth, Géza. 1987. A pesti dal. In Elfeledett Álom, Csáth Géza válogatott Mūvei. Edited by Kálmán Vargha. Budapest: Kozmosz Könyvek.

Editor. 1996. A Budapesti Kávéházak listaja. Budapesti Negyed 12-13: 296-315.

Fábri, Anna. 1993. Írók, Költõk, Törzshelyek. Budapesti Negyed 1: 161-9.

Faragó, Miklós. 1915. A Royal börzédzsungeljeben. Az Est, September 30, 14.

Fényes, László. 1914. Takarodjék innen. Az Est, June 18, 7.

Fényes, László. 1915. A kávésok, a drágulás és a habtejszín. Az Est, April 11, 2.

Gluck, Mary. 2013. The Budapest Coffeehouse and the making of 'Jewish modernity' at the Fin de Siecle. Journal of the History of Ideas 7: 289-306. [CrossRef]

Gluck, Mary. 2016. The Invisible Jewish Budapest. Madison: University of Wisconsin Press.

Gundel, Imre, and Harmath Judit. 1979. A vendéglátás emlékei, Közgazdasági és Jogi könyvkiadó. Budapest: Közgazdasági és Jogi Könyvkiadó.

Hay, János. 2002. Négyszáz éves kapucíner, Magyar írók novellái a kávéházakról. Budapest: Palatinus.

Heltai, Jenõ. 1911a. Az utolsó bohém. Pesti Hírlap, June 27.

Heltai, Jenõ. 1911b. Versei. Budapest: Nyugat.

Heltai, Jenõ. 1913. Fûzfasíp. Budapest: Nyugat.

Herceg, Ferenc. 1903. Andor és András. Budapest: Singer és Wolfner Irodalmi Intézet.

Herczeg, Ferenc. 1985. A gótikus ház. Budapest: Szépirodalmi Könyvkiadó.

Hess, Jonathan. 2010. Middlebrow Literature and the Making of German-Jewish Identity. Palo Alto: Stanford University Press.

Karinthy, Frigyes. 1958. Egy téma irót keres. Budapest: Szépirodalmi könyvkiadó.

Kóbor, Tamás. 1902. A régi kedves. Pesti Hirlap, February 2.

Kóbor, Tamás. 1999. Guszti, a fõpincér. Budapesti Negyed 1: 160-64.

Lackó, Miklos. 1995. Zsidók a Budapesti Irodalomban 1890-1930. Budapesti Negyed 8: 107-26.

Liberles, Robert. 2012. Jews Welcome Coffee: Tradition and Innovation in Early Modern Germany. Waltham: Brandeis University Press.

Márai, Sándor. 1945. Az Iró és a Város. Budapest: Budapest Folyóirat.

Nagy, Lajos. 1956. A lázadó ember. Budapest: Szépirodalmi könyvkiadó.

Gerõ, Ödön (Viharos). 1891. Az én fõvárosom. Budapest: Révai.

S.F. 1916. Panaszos levél a pesti kávéházakról. Az Est, January 13, 12.

Székely, Ferenc. 1918. A kagál. Borszem Jankó, October 1.

Szép, Ernõ. 1913. Egy magános éjszakai csavargás kimeritõ leirása. Nyugat 3: 202-5.

Szép, Ernõ. 1914a. Nagymester. Az Est, April 16, 4.

Szép, Ernõ. 1914b. Ujságolvasók. Az Est, April 11, 4. 
Szép, Ernõ. 1916. Az Élet dolgai. Az Est, April 26, 5.

Szép, Ernõ. 1917. Gyufa és egyéb elbeszélések. Az Est, February 1, 7.

Szép, Ernõ. 1945. Kati gyerek ki. Budapest, 119.

Szép, Ernõ. 1998. What a beautiful wheather, in Balázs Draveczky, Szép Ernõ és a Kávéház. Népszabadság, November 12, 42.

Szép, Ernõ. 2003. A Billiárd. In Szép Ernő összes versei. Szeged: Szukits Kiadó.

Viharos, Utazás. 1908. Pestrõl Budapestre. Pesti Napló, February 9, 7.

Zeke, Gyula. 1995. A nagyvárosi kúltúra új formái és a zsidóság. Budapesti Negyed 8: 90-106.

Zsolt, Béla. 2002. Az oleander árnyékában. In Négyszáz éves kapucíner, Magyar írók novellái a kávéházakról. Edited by János Hay. Budapest: Palatinus, p. 277. 